Volume 1, Nomor 2, September 2019, pp 64-73. Copyright (C 2019 JAFTA, Program Studi Magister Akuntansi, Fakultas Ekonomi, Universitas Kristen Maranatha. ISSN: 2654-4636| E-ISSN: 2656-758X https://journal.maranatha.edu/index.php/jafta

\title{
Pengaruh Subsidi Listrik Terhadap Konsumsi Rumah Tangga Di Indonesia Periode 2004-2017
}

\author{
Oleh: \\ Sugiartiningsih \\ Fakultas Ekonomi Universitas Widyatama \\ email: sugiarti.ningsih@widyatama.ac.id
}

\begin{abstract}
ABSTRAK
Tujuan penelitian ini untuk mengetahui pengaruh subsidi listrik terhadap konsumsi rumah tangga di Indonesia periode 2004-2017. Metode penelitian yang digunakan adalah deskriptif kuantitatif dengan pemodelan regresi sederhana. Dari hasil pengolahan data diprediksi akan memperoleh hubungan yang searah atau positif antara kedua variabel tersebut. Hal ini sesuai dengan dasar berfikir mikroekonomi dimana subsidi listrik akan berdampak penurunan biaya produksi bagi produsen yang pada tahap selanjutnya akan meningkatkan daya saing penawaran produk Indonesia. Kemudian dari sisi makroekonomi kondisi tersebut akan mendorong meningkatkan daya beli sehingga nilai pendapatan nasional riil juga meningkat yang akhirnya menaikkan pula konsumsi rumah tangga di Indonesia.
\end{abstract}

Kata kunci: Subsidi, Pendapatan, Konsumsi Rumah Tangga

\section{ABSTRACT}

The purpose of this study was to determine the effect of electricity subsidies on household consumption in Indonesia in the period 2004-2017. The research method used is quantitative descriptive with simple regression modeling. From the results of data processing it is predicted to obtain a direct or positive relationship between the two variables. This is in accordance with the basic microeconomic thinking where electricity subsidies will have an impact on reducing production costs for producers which in the next stage will increase the competitiveness of Indonesian product offerings. Then from the macroeconomic point of view these conditions will encourage increased purchasing power so that the value of real national income also increases which ultimately also increases household consumption in Indonesia.

Keywords: Subsidies, Income, Household Consumption

\section{PENDAHULUAN}

Pembangunan ekonomi Indonesia yang berupaya mewujudkan masyarakat adil dan makmur terlihat dari peran pemerintah dalam menyediakan barang-barang umum antara lain listrik. Kesadaran campur tangan pemerintah melalui Badan Usaha Milik Negara (BUMN) selain beralasan untuk melindungi hajat hidup orang banyak adalah ingin menekankan pada sisi pemerataan terhadap penggunaan listrik (Sadono Sukirno, 2000).

Tindakan pemerintah sebagai monopolis terhadap konsumen listrik adalah mengatur tarif listrik berdasarkan peruntukan dan dayanya (Kementerian
Energi, 2016). Dalam operasionalnya tarif listrik untuk peruntukan dibagi menjadi tujuh segmen yaitu rumah tangga, bisnis, publik, industri, sosial, traksi dan curah. Kemudian dari dayanya mulai penggunaan 0 s.d 450 VA; 900 VA, 1300 VA; 2.200 VA s.d. 5500 VA; 6.600 s.d. 200kVA dan di atas $200 \mathrm{kVA}$ (Kementerian Energi, 2016).

Dari pengklasifikasian tersebut menunjukkan ditinjau dari perspektif mikroekonomi pemerintah kita sangat respon terhadap subsisdi energi khususnya listrik. Kemungkinan bagi kelompok pengusaha terutama usaha kecil dan besar kebijakan tersebut dianggap lebih menguntungkan karena akan mampu bersaing dengan harga yang lebih rendah. Demikian 
JAFTA — Vol. 1 Nomor 2, September (2019)

pula bagi sektor rumah tangga juga mampu meningkatkan daya beli yang akhirnya berdampak pula terhadap kesejahteraan penduduk Indonesia.

Setelah era reformasi perhatian pemerintah terhadap subsidi listrik di Indonesia masih terlihat cukup besar. Terutama masa pemerintahan SBY I dan II subsidi listrik cenderung meningkat dari Rp 2 trilyun tahun 2004 menjadi Rp 103,8 trilyun tahun 2014. Peningkatan subsidi listrik tersebut pernah mendapatkan kritik dari Dana Moneter Internasional (IMF) dan Bank Dunia karena dapat menimbulkan konsekuensi negatif. Kemudian memasuki pemerintahan Jokowi I dengan segala keberaniannya telah berupaya menghapuskan subsidi listrik yang ditandai dengan penurunan mencapai Rp 73,1 trilyun tahun 2015; Rp 63,1 trilyun tahun 2016 dan Rp 50,6 trilyun tahun 2017. (https://www.indonesia-

investments.com/id/keuangan/angka-ekonomi-

makro/inflasi-di-indonesia/item254?)

Kondisi subsidi listrik yang senantiasa meningkat disinyalir akan berpengaruh terhadap konsumsi masyarakat Indonesia. Terutama bagi sektor rumah tangga akan membantu meningkatkan daya beli terhadap barang dan jasa akhir yang diperlukan. Apalagi bila melihat realitasnya sampai sekarang terbukti konsumsi sektor rumah tangga penyumbang pertumbuhan ekonomi tertinggi di Indonesia (Sugiarti, 2015). Jadi muncul dugaan bahwa subsidi listrik akan meningkatkan konsumsi rumah tangga di Indonesia.

Untuk mengetahui perkembangan subdidi listrik dan konsumsi rumah tangga di Indonesia dapat dilihat pada Tabel 1 berikut:

Tabel 1. Perkembangan Subsidi Listrik Dan Konsumsi Rumah Tangga Di Indonesia Periode 2004-2017

\begin{tabular}{ccc}
\hline Tahun & $\begin{array}{c}\text { Subsidi } \\
\text { Listrik } \\
\text { (triliun Rp) }\end{array}$ & $\begin{array}{c}\text { Consume } \\
\text { (triliun Rp) }\end{array}$ \\
\hline 2004 & 2,3 & $1.004,10$ \\
2005 & 8,9 & $1.043,80$ \\
2006 & 30,4 & $1.076,90$ \\
2007 & 33,1 & $1.130,80$ \\
2008 & 83,9 & $1.191,20$ \\
2009 & 49,5 & $1.249,10$ \\
2010 & 57,6 & $3.786,10$ \\
2011 & 90,4 & $3.977,30$ \\
2012 & 94,6 & $4.195,80$ \\
2013 & 99,9 & $4.423,40$ \\
2014 & 103,8 & $4.651,00$ \\
2015 & 72,1 & $4.881,60$ \\
2016 & 63,1 & $5.126,00$ \\
2017 & 50,6 & $5.379,50$ \\
\hline
\end{tabular}

Dari Tabel 1 di atas terlihat selama era pemerintahan SBY I dan II tarif listrik hanya turun di tahun 2009 saja yaitu dari Rp 83,9 trilyun menjadi Rp 49,5 trilyun. Kemudian dari tahun 2010 sampai dengan 2014 subsidi listrik naik dengan rata-rata $\mathrm{Rp} 4.206,72$ trilyun per tahun. Kemudian memasuki era Jokowi I tarif listrik justru menurun hingga Rp 50,6 trilyun pada tahun 2017. Sedangkan 
JAFTA — Vol. 1 Nomor 2, September (2019)

konsumsi rumah tangga di Indonesia terlihat meningkat setiap tahunnya dari Rp 1004,1 trilyun tahun 2004 menjadi Rp 5379,5 trilyun tahun 2017.

Dengan adanya fluktuasi dari subsidi listrik yang diikuti oleh kenaikan konsumsi rumah tangga di Indonesia mendorong untuk meneliti pengaruh subsidi listrik terhadap konsumsi rumah tangga di Indonesia periode 2004-2017.

\section{Perumusan Masalah}

Berdasarkan gambaran dari latar belakang masalah maka rumusan masalahnya adalah bagaimanakah pengaruh subsidi listrik terhadap konsumsi rumah tangga di Indonesia periode 20042017.

\section{LANDASAN TEORI DAN HIPOTESIS}

\section{Pengaruh Subsidi Terhadap Harga Output Dan}

Kebijakan Fiskal merupakan salah satu wujud campur tangan pemerintah dalam perekonomian suatu negara (Sadono Sukirno, 2000). Kebijakan Fiskal dapat diterapkan melalui penerimaan atau pengeluaran pemerintah yang berupa pengenaan pajak dan pemberian subsidi (Lia Amaliawati, 2016). Subsidi dilakukan oleh pemerintah karena kelebihan produksi yang terus menerus bertambah akibat harga yang teralalu tinggi. Sasaran subsidi adalah untuk memberikan jaminan harga yang tepat bagi produsen maupun konsumen (Sadono Sukirno, 2012).

Subsidi adalah pemberian pemerintah kepada produsen untuk mengurangi biaya produksi yang ditanggung produsen. Pengaruh subsidi terhadap harga secara konkrit dapat terlihat dari Gambar 1 berikut:

Gambar 1. Pengaruh Subsidi Terhadap Harga Output Dan Konsumsi

\section{Konsumsi Rumah Tangga}

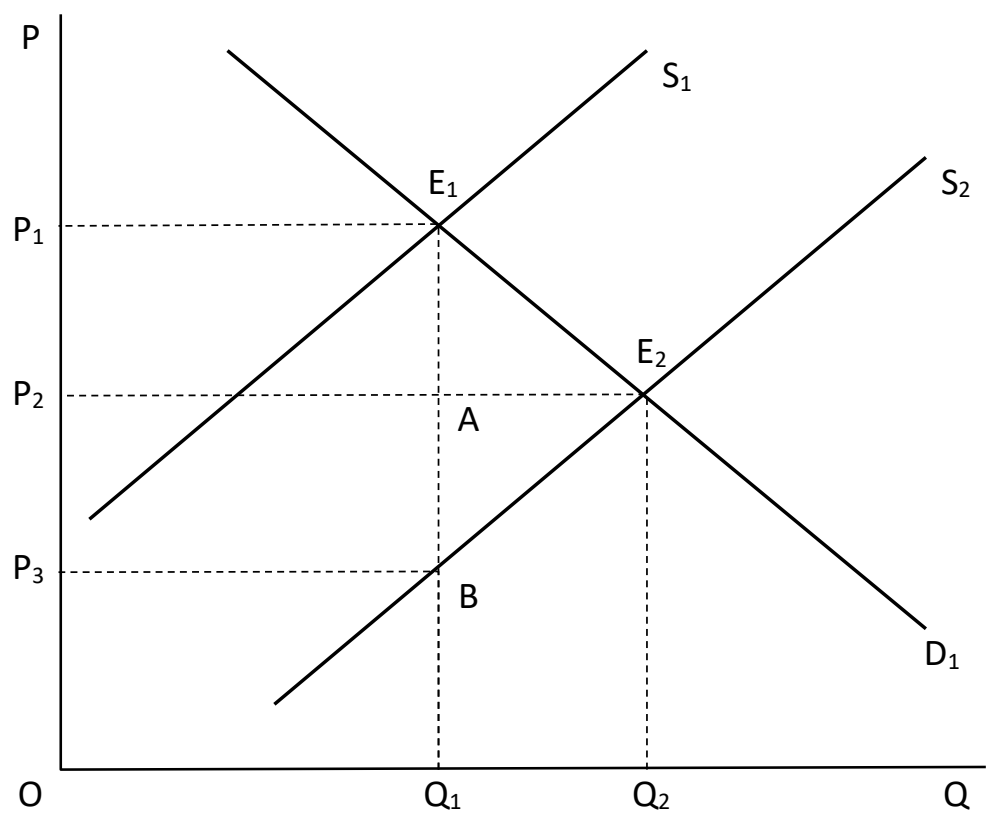

Dari Gambar 1 di atas terlihat sebelum diberikan subsidi nilai keseimbangan pasar ditunjukkan oleh perpotongan D1 dan S1 di titik E1 dengan nilai output sebesar OQ1 dan harga sebesar OP1. Kemudian setelah diberikan subsidi maka 66 berdampak biaya produksi yang ditanggung produsen lebih rendah sehingga peluang untuk menwarkan output naik dari S1 ke S2, sedangkan kurva permintaan tetap D1. Dari sudut pandang ilmu ekonomi peristiwa ini dinamakan perubahan 
JAFTA — Vol. 1 Nomor 2, September (2019)

kesimbangan secara parsial. Dengan demikian nilai keseimbangan baru ditunjukkan oleh perpotongan D2 dengan S2 di titk E2. Pada titik E2 ini akan terjadi harga turun menjadi OP2. Proses penurunan harga ini adalah besarnya subsidi yang diterima konsumen secara parsial. Sedangkan secara agregat penerimaan subsidi oleh konsumen adalah P1P2AE1. Subsidi yang diterima produsen secara parsial adalah P2P3 dan secara agregat adalah P2P3 $\mathrm{AB}$.

Besar kecilnya subsidi yang diterima baik oleh produsen maupun konsumen sangat tergantung dari elastisitasnya. Semakin elastis kurva penawaran produsen subsidi yang diterima konumen semakin besar yang ditunjukkan oleh perpindahan yang lebih jauh dari titik E ke E1, sedangkan subsidi yang diterima produsen lebih rendah. Demikian pula sebalinya bila kasus elastisitas permintaan adalah elastis akan berdampak penurunan harga dari titik E ke E1 lebih pendek sehingga keuntungan subsidi yang diterima konsumen lebih rendah daripada produsen (Lia Maliawati, 2016).

Dalam perspektif makroekonomi subsidi listrik memiliki dampak terhadap peningkatan daya beli sektor rumah tangga. Dengan adanya subsidi listrik akan berdampak harga barang-barang dan jasa yang diterima rumah tangga menjadi lebih rendah. Hal ini akan terkesan pendapatan riil masyarakat menjadi lebih tinggi sehingga akan menaikkan jumlah barang dan jasa yang dapat dikonsumsi (Sadono Sukirno, 2000).

\section{Kerangka Pemikiran}

Persediaan barang publik yang menjadi kewajiban pemerintah suatu negara sangatlah sesuai dengan cirikhas sistem ekonomi yang menyatakan bahwa campur tangan pemerintah pasti diperlukan dalam perekonomian. Ide dilibatkannya peran pemerintah sangat penting bagi Indonesia untuk menjamin agar kebutuhan barang publik yaitu listrik dapat dinikmati seluruh masyarakat Indonesia. Solusi yang paling bijak dilakukan pemerintah adalah dengan memberikan subsidi listrik.

Sementara jumlah penduduk Indonesia setelah era reformasi terjadi peningkatan disinyalir akan meningkatkan konsumsi di Indonesia. Terlebih dengan adanya subsidi listrik akan membantu meningkatkan daya beli terhadap barang dan jasa yang diperlukan untuk memuaskan kebutuhan. Mengingat sebagian besar kontribusi pertumbuhan ekonomi Indonesia masih didominasi sektor rumah tangga, maka dapat diakatakan subsdi listrik akan meningkatkan konsumsi rumah tangga di Indonesia.

Pengaruh subsidi listrik terhadap konsumsi rumah tangga di Indonesia periode 2004-2017 dapat digambarkan sebagai berikut

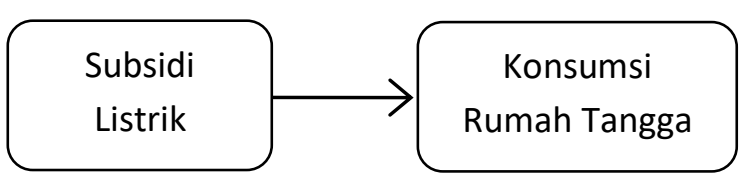

\section{Hipotesis Penelitian}

Pengaruh subsidi listrik terhadap konsumsi rumah tangga di Indonesia periode 2004-2017

Pemberian subsidi listrik oleh pemerintah akan mendorong kenaikan konsumsi rumah tangga di Indonesia. Pernyataan tersebut sesuai dengan konsep dasar makroekonomi bahwa peran kebijakan fiskal dapat terlihat dari sisi pengeluaran yang diwujudkan dengan pemberian subsidi. Dampak utama yang dirasakan sektor rumah tangga sebagai konsumen barang dan jasa adalah harga produk yang lebih rendah sehingga pendapatan riil yang naik ini akan mampu meningkatkan daya beli yang akhirnya meningkatkan pula konsumsi rumah tangga di Indonesia. 
JAFTA — Vol. 1 Nomor 2, September (2019)

Penelitian yang berkaitan dengan konsumsi di Indonesia telah dilakukan sendiri oleh peneliti dengan menggunakan variabel bebas yaitu pendapatan nasional. Kemudian dari hasil perhitungan yang dilakukan selama periode 19972013 diperoleh hubungan positif dan signifikan (Sugiarti, 2015). Dengan demikian bila masyarakat menerima subsidi tentu meningkatkan kesejahteraan masyarakat yang terlihat dari kemampuan membeli barang dan jasa yang lebih tinggi.

Berdasarkan pernyataan tersebut maka hipotesis yang diajukan adalah :

$H a: \quad$ Subsidi listrik akan berpengaruh positif terhadap konsumsi rumah tangga di Indonesia.

\section{METODE PENELITIAN}

Metode penelitian menggunakan pendekatan deskriptif kuantitatif yang secara spesifik menggambarkan hubungan kausal antara subsisdi listrik dengan konsumsi rumah tangga di Indonesia. Data yang digunakan dalam penelitian ini adalah data sekunder, dimana untuk variabel subsidi listrik bersumber dari https://www.indonesia-

investments.com/id/keungan/angka-ekonomi-

makro/inflasi-di-indonesia/item254?.

Sedangkan konsumsi akhir sektor rumah tangga di Indonesia bersumber dari Asian Development Bank. Penggunaan data tahun dari 2004 disebabkan kita sudah masuk era reformasi dan pemerintahan SBY I yang sangat respon terhadap kebijakan fiskal. Adapun batasan tahun 2017 disebabkan tahun tersebut selain sudah masuk pemerintahan Jokowi I juga terlihat kesungguhan pemerintah untuk dapat melepaskan dari subsidi listrik.

Pemodelan yang menganalisis hubungan subsidi listrik dengan konsumsi akhir sektor rumah tangga di Indonesia periode 2004-2017 dengan menggunakan persamaan regeresi sebagai berikut:

$$
C R T=a+b S L
$$

dimana:

$$
\begin{aligned}
\text { CRT }= & \text { nilai konsumsi akhir sektor rumah } \\
& \text { tangga di indonesia dalam satuan } \\
& \text { trilyun rupiah } \\
\mathrm{SL}= & \text { besarnya subsidi listrik di } \\
& \text { indonesia dalam satuan trilyun } \\
& \text { rupiah }
\end{aligned}
$$

\section{Rancangan Uji Hipotesis}

Dalam penelitian ini akan digunakan uji t,

$\mathrm{F}$ dan $\mathrm{R}^{2}$. Untuk ketiga pengujian tersebut dapat diuraikan sebagai berikut:

\section{Uji Parsial Persamaan Regresi}

Persamaan Pengaruh Subsidi Listrik Terhadap

Konsumsi RumahTangga Di Indonesia Periode 2004-2017

Subsidi listrik berpengaruh terhadap konsumsi rumah tangga di Indonesia periode 2004 2017.

Ho $: \rho<0$ subsidi listrik berpengaruh negatif terhadap konsumsi rumah tangga di Indonesia periode 2004-2017

Ho : $\rho>0$ subsidi listrik berpengaruh positif terhadap konsumsi rumah tangga di Indonesia periode 2004-2017

Ho ditolak bila $\rho>0$

\section{Uji Simultan Persamaan Regresi}

Persamaan Pengaruh Subsidi Listrik Terhadap Konsumsi Rumah Tangga Di Indonesia Periode 2004-2017

Subsidi listrik berpengaruh terhadap konsumsi rumah tangga di Indonesia periode 2004 2017.

Ho $: \rho=0 \quad$ Subsidi listrik secara simultan tidak berpengaruh terhadap konsumsi rumah tangga di Indonesia periode 2004-2017 
JAFTA — Vol. 1 Nomor 2, September (2019)

\section{Ho $: \rho \neq 0$ Subsidi listrik secara simultan berpengaruh terhadap konsumsi rumah tangga di Indonesia periode 2004-2017}

Ho ditolak bila $\rho \neq 0$

\section{HASIL DAN PEMBAHASAN}

Hasil pengolahan data-data terhadap persamaan regresi sederhana periode 2004-2017 diperoleh hasil:

\begin{tabular}{lrrrrrrrr} 
& \multicolumn{9}{c}{ Standard } \\
& Coefficients & Error & $t$ Stat & P-value & Lower 95\% & Upper 95\% & $95,0 \%$ & $\begin{array}{r}\text { Uower } \\
95,0 \%\end{array}$ \\
\hline $\begin{array}{l}\text { Intercept } \\
\text { Subsidi }\end{array}$ & 940,38972 & 821,92015 & 1,1441376 & 0,2748764 & $-850,42046$ & 2731,1999 & $-850,42046$ & 2731,1999 \\
Listrik & 0,3564776 & 0,1210656 & 2,9444993 & 0,012269 & 0,0926983 & 0,6202569 & 0,0926983 & 0,6202569 \\
\hline
\end{tabular}

Dari hasil regresi tersebut $\mathrm{Y}$ atau CRT adalah variabel konsumsi rumah tangga di Indonesia sedangkan $\mathrm{X}$ atau SL adalah subsidi listrik yang diberikan oleh pemerintah Indonesia. Bila subsidi listrik belum diberikan oleh pemerintah Indonesia maka konsumsi rumah tangga mencapai nilai sebesar Rp 940,3897171 trilyun. Hasil perhitungan tersebut menunjukkan tingginya konsumsi sektor rumah tangga di Indonesia dalam upaya memenuhi kebutuhannya. Subsidi listrik yang diberikan oleh pemerintah selama periode 2004-2017 memiliki hubungan searah terhadap nilai konsumsi sektor rumah tangga di Indonesia. Dimana naiknya subsidi sebesar Rp. 1 trilyun akan meningkatkan konsumsi rumah tangga sebesar Rp 0,356477578 trilyun.

\section{Pengujian Statistik}

Analisis signifikansi dari nilai koefisien persamaan regresi yang digunakan dalam penelitian ini dengan menggunakan uji $\mathrm{t}$ dan $\mathrm{F}$ statistik.

\section{Uji Parsial Persamaan Regresi}

$H a$ : Subsidi listrik akan berpengaruh positif terhadap konsumsi rumah tangga di Indonesia periode 2004-2017.

Dari hasil pengujian t-statistik diperoleh variabel subsidi listrik di Indonesia mempunyai nilai thitung sebesar 2,9444. Nilai t tersebut terbukti lebih besar dari t-tabel pada tingkat signifikansi 5\% (ttabel $=2,179)($ Salvatore, 2003)

\section{Uji Simultan Persamaan Regresi}

$H a$ : Subsidi listrik berpengaruh terhadap konsumsi rumah tangga di Indonesia periode 2004-2017.

Dari hasil pengujian F-statistik terlihat seperti Tabel berikut.

\begin{tabular}{lrrrrr} 
ANOVA & & & & \\
& $d f$ & SS & MS & F ignificance $F$ \\
\hline Regression & 1 & 17922375 & 17922375 & 8,6700764 & 0,012269 \\
Residual & 12 & 24805837 & 2067153,1 & & \\
Total & 13 & 42728212 & & & \\
\hline
\end{tabular}


Nilai F-statistik ini sebesar 8,6700 terlihat lebih besar daripada F-tabel pada tingkat signifikansi 5\% $($ F-tabel $=4,67)($ Salvatore, 2003).

\section{$\mathbf{U j i} \mathbf{R}^{2}$}

Untuk mengetahui sampai seberapa besar kontribusi variabel subsidi listrik terhadap konsumsi rumah tangga di Indonesia periode 20042017 dapat dilihat pada Tabel berikut:

\begin{tabular}{ll}
\hline Regression Statistics & \\
\hline Multiple R & 0,64765008 \\
R Square & 0,41945062 \\
Adjusted R Square & 0,37107151 \\
Standard Error & 1437,75974 \\
Observations & 14 \\
\hline
\end{tabular}

Dari hasil Tabel tersebut terlihat kontribusi subsidi listrik terhadap konsumsi rumah tangga di Indonesia sebesar 0,4194 atau 41,94\%. Sedangkan selebihnya $50,06 \%$ adalah variabel lain diluar variabel bebas yang digunakan. Kontribusi subsidi listrik tersebut dapat dikatakan cukup besar dalam upaya meningkatkan daya beli terhadap barang dan jasa yang dikonsumsinya. Hal ini disebabkan bahwa subsidi sebenarnya hanya bersifat menolong agar produsen dapat bangkit dan mampu bersaing di kemudian hari. Terlebih subsidi listrik yang diberikan pemerintah akan menekan biaya produksi yang harus ditanggungnya apakah sebagai biaya operasional ataukah tetap (Liming Guan, Don R. Hansen, Maryanne M. Mowen, 2009). Bahkan dengan pemberian subsidi listrik setidaknya memberikan kemudahan bagi semua sektor baik rumah tangga atau perusahaan khususnya UMKM untuk dapat beraktifitas lebih optimal yang terlihat dari konsumsi sektor rumah tangga terus meningkat.

\section{Pembahasan}

Persamaan Pengaruh Subsidi Listrik Terhadap Konsumsi Rumah Tangga Di Indonesia Periode 2004-2017.

Ha: Subsidi listrik berpengaruh positif terhadap konsumsi rumah tangga di Indonesia periode 2004 2017

Variabel subsidi listrik berhubungan positif terhadap konsumsi rumahtangga di Indonesia telah sesuai dengan konsep berpikir ilmu ekonomi baik mikroekonomi maupun maupun makroekonomi. Subsidi sebagai alat dalam pelaksanaan kebijakan fiskal pasti memberikan keringanan bagi produsen maupun konsumen dalam menerima keputusan harga. Dalam persepektif mikroekonomi pemberian subsidi listrik akan berdampak pada harga listrik yang harus dikeluarkan sesuai dengan batasan daya yang ditetapkan oleh pemerintah. Kebijakan ini tentu memberikan keringanan/kemudahan bagi pengguna untuk bersikap lebih efektif dan efisien (Robert $\mathrm{S}$. Pindyck dan Daniel L. Rubinfeld, 2012).

Bagi sektor rumah tangga kondisi ini dapat dilakukan dengan pemanfaatan listrik seperlunya dengan pola hidup yang sederhana . Sebagai contoh adalah penggunaan pakaian lebih dari satu kali, pemakaian mesin cuci yang hemat listrik serta setrika hanya yang dianggap perlu-perlu saja. Selain itu untuk peneranganpun hanya menggunakan untuk ruang tertentu dengan watt yang rendah. Gaya hidup yang berhemat ini bila diikuti disiplin tinggi ternyata mampu menekan anggaran rumah tangga untuk pembayaran tarif listrik. Sesuai realitas penggunaan listrik yang sangat tinggi dibandingkan dengan yang hemat tersebut memiliki selisih atau margin yang sangat tinggi/bulan sehingga akan mampu meningkatkan konsumsi akhir mereka lebih tinggi lagi.

Pernyataan tersebut didukung oleh Destry

(2019) bahwa kontribusi tinggi pertumbuhan 
JAFTA — Vol. 1 Nomor 2, September (2019)

ekonomi Indonesia adalah dari konsumsi rumah tangga. Untuk lebih meningkatkan peran rumah tangga dalam meningkatkan pertumbuhan ekonomi Indonesia haruslah dari dua arah yaitu dari sisi pendapatan dan harga. Pendapatan dapat ditingkatkan dengan menciptakan peluang kerja seluas-luasnya, sedangkan untuk penekanan harga serendah-rendahnya antara lain dengan memberikan subsidi seperti listrik.

Demikian pula dengan sektor rumah tangga lain yang masih belum memiliki tempat tinggal/rumah sendiri dengan adanya subsidi listrik ini juga dipermudah untuk dapat membeli rumah/tanah di wilayah yang jauh dari perkotaan. Sedikit gambaran untuk daerah yang masuk klasifikasi pegunungan terbukti harga setumbak tanah masih murah dibandingkan yang berdekatan dengan pusat perkotaan. Pertimbangan tersebut dilandasi bahwa infrastruktur listrik belum dapat masuk dan mereka mau hidup dengan menggunakan penerangan tradisional atau cempor. Berarti subsidi listrik diwilayah tersebut perlu diperhatikan lebih seksama oleh pemerintah demi menciptakan pemerataan. (Mirna Nurtika Sari, 2019)

Bahkan penggunaan listrik bersubsidi justru masih dinikmati oleh sebagian sektor rumah tangga yang hidup di kota dengan mengkontrak rumah. Terkadang ada berbagai tipe rumah yang sengaja dipasang dengan daya terbatas mendorong mereka untuk berhemat menggunakan listrik misalkan hanya untuk penerangan, setrika dan televisi saja. Selama kita puas dengan penggunaan yang terbatas tersebut maka dapat dipastikan sektor rumah tangga tersebut akan menikmati tarif yang rendah dari pemberian subsidi listrik tersebut. Sebaliknya bila dalam mengkontrak rumah yang memiliki $\mathrm{kWh}$ tinggi terkadang justru membebani mahasiswa pengguna daya listrik yang terbatas karena pemanfaatan listrik untuk berbagai barang elektronik oleh pihak lain dalam rumah tersebut.

Realitas ini terjadi pula dalam segmen perdagangan di kota-kota di Indonesia. Seperti diketahui mayoritas penduduk yang tinggal diperkotaan berkiprah sebagai usaha kecil. Dampak subsidi listrik ini dinikmati pula oleh para pengusaha kecil yang menggunakan fasilitas listrik dengan cara menginduk pada sektor rumah tangga. Tidak dapat dipungkiri kemajuan perkotaan sangat didukung oleh peran UMKM terutama Pedagang Kaki Lima (PKL) mulai produk kuliner hingga produk manufaktur lainnya. Kebiasaan mereka adalah memanfaatkan lahan di depan rumah orang lain sekaligus ikut menggunakan listrik dari pemilik rumah atau usaha formal tersebut. Meskipun penggunaan listrik ini adalah bersifat internal diprediksi tetap menguntungkan bagi pemilik rumah maupun pelaku usaha tersebut.

Dengan kerjasama ini langkah berikutnya tinggal kepandaian PKL untuk memanage proses produksinya agar dapat menekan biaya dan meningkatkan sumber penerimaan produsen. Bagaimanapun subsidi listrik ini mampu menekan harga bagi produsen dan selanjutnya meningkatkan daya beli terhadap produk akhir yang dijualnya yang akhirnya secara makro mampu meningkat nilai konsumsi akhir sektor rumahtangga di Indonesia. (Muhammad Chatib Basri, Resep Tua Mengatasi Perlambatan Ekonomi, 18-24 Mei 2015)

\section{KESIMPULAN DAN SARAN}

\section{Kesimpulan}

Pada persamaan pengaruh subsidi listrik terhadap konsumsi rumah tangga di Indonesia periode 2004-2017 diperoleh hubungan positif dan telah sesuai dengan konsep dasar berpikir mikroekonomi dan makroekonomi. 


\section{Saran}

Untuk penelitian mendatang sebaiknya dapat dikaji lebih dalam pengaruh subsidi listrik terhadap daya beli sebagai variabel terikat supaya dapat memperoleh gambaran nyata pengaruh subsidi bagi sektor rumah tangga di Indonesia.

\section{DAFTAR PUSTAKA}

Asian Development Bank, Final Consumption:http://www.adb.org/publicati ons/key-indicators-asia-and-pacific-2017.

Destry Damayanti, Kamis 8 Agustus 2019, Pelonggaran Jangka Panjang, Ekonomi \& Bisnis, Kompas Halaman 14, Jakarta.

Dominick Salvatore,2003, Managerial Economics dalam Perekonomian Global Edisi Keempat Jilid 2, Penerbit Erlangga, Jakarta

Kementerian Energi Dan Sumber Daya Mineral Republik Indonesia, 2016, Peraturan Menteri Energi Dan Sumber Daya Mineral Republik Indonesia Nomor 28 Tahun 2016 Tentang Tarif tenaga Listrik Yang Disediakan Oleh PT Perusahaan Listrik Negara (Persero), Jakarta.

Lia Amaliawati dan Asfia Murni, 2017, Ekonomika Mikro Edisi Revisi, Refika Aditama

LimingGuan, Don R. Hansen, Maryanne M. Mowen, 2009, Cost Management Sixth Edition, South-Western Cengage Learning.

Mirna Nurtika Sari, Kamis 18 Agustus 2019, Staf Administrasi Dan Pelayanan Masyarakat PLN Ujung Berung, Komunikasi Interpersonal, Bandung.

Muhammad Chatib Basri,18-24 Mei 2015, Resep Tua Mengatasi Perlambatan Ekonomi, Tempo, Jakarta.

Robert S. Pindyck dan Daniel L. Rubinfeld, 2012, Mikroekonomi Edisi Kedelapan, Penerbit Erlangga, Jakarta.

Sadono Sukirno, 2012, Mikro Ekonomi Teori Pengantar, PT Raja Grafindo Persada, Jakarta.

Sadono Sukirno, 2000, Pengantar Teori Makroekonomi Edisi Kedua, PT Raja Grafindo Persada, Jakarta.

Sugiartiningsih, 2015, Pengaruh Pendapatan Nasional Terhadap Konsumsi Di Indonesia Sebagai Upaya Meningkatkan
Kesejahteraan Rakyat Periode 1997-2013, Seminar Konferensi Nasional "Optimalisasi Community Well-being Dalam Perspektif Multidisipliner” Fakultas Psikologi Universitas Kristen Maranatha, Bandung.

https://www.indonesia-

investments.com/id/keuangan/angka-

ekonomi-makro/inflasi-di-

indonesia/item 254 ? 
JAFTA — Vol. 1 Nomor 2, September (2019) 